\title{
Anaerobic and aerobic skin bacteria before and after skin-disinfection with chlorhexidine: An experimental study in volunteers
}

\author{
M. L. NIELSEN, D. RAAHAVE, J. G.STAGE, AND T. JUSTESEN \\ From the Department of Clinical Bacteriology, Institute of Medical Microbiology and Department of Surgical \\ Gastroenterology, Rigshospitalet, University of Copenhagen, Denmark
}

SYNOPSIS The amount, composition, and localization of anaerobic and aerobic bacteria in the normal skin before and after disinfection were the subject of a volunteer study. The superficial bacterial flora were sampled by velvet pad imprints, and the deep flora were determined from whole skin biopsies. Only one anaerobic species, Propionebacterium acnes, was encountered even though other and more strict anaerobic bacteria could have been grown with the anaerobic technique employed. Staphylococcus albus dominated among the aerobic superficial bacteria, while diphtheroids, Micrococcus spp., and lactobacilli occurred sporadically. The deep aerobic bacteria were present in a significantly greater amount than the anaerobic. A two-step cleansing/disinfection procedure was evaluated in vivo in volunteers as well as in surgical patients, and aqueous cetrimide/ chlorhexidine (Savlon) followed by chlorhexidine in alcohol (Hibitane) almost eradicated both the superficial and deep anaerobic and aerobic skin flora.

Controversial views exist on the amount, composition, and localization of the bacterial skin flora. This diversity of opinion may be due to the great differences in the sampling and culturing techniques employed. A survey has been given by Marples (1969), and Montes and Wilborn (1970) have demonstrated by electron microscopy that while some bacteria are situated on the skin surface, the bulk of the bacterial flora is localized in hair follicles and crypts of sebaceous glands.

The present study was undertaken to determine quantitatively and qualitatively the anaerobic and aerobic skin bacteria, attempting to distinguish between the superficial and deep skin flora. A specific aim was to examine the efficiency of a cleansing/disinfection procedure on anaerobic skin bacteria, anaerobic contamination of clinical samples having occurred in a previous investigation (Nielsen et al, 1974), as well as to ascertain the value of the procedure with regard to the operation site (Raahave, 1973).

\section{Volunteers, Patients, and Methods}

The study was made on 14 volunteers without any Received for publication 12 May 1975. disease of the skin and 14 surgical patients. In the volunteers (age and sex shown in table I), all samples were taken from the thigh. They had an ordinary bath two days before sampling, and were asked to avoid any further cleansing of the skin area in question. The 14 patients (eight women and six men, 16-71 yr, median $58 \mathrm{yr}$ ) were investigated prior to abdominal surgery.

\section{GENERAL PROCEDURES}

In the volunteers we took all samples from the lateral aspect of the upper part of the thigh employing local anaesthesia, lidocaine chloride $1 \%$ with norepinephrine. The solution was deposited subcutaneously around the area to be sampled and at a distance of $2-3 \mathrm{~cm}$. A velvet pad imprint $\left(9 \mathrm{~cm}^{2}\right)$ was then taken from the skin, followed by a skinbiopsy $\left(2 \mathrm{~cm}^{2}\right)$, excised by knife. After cleansing and disinfection of the same skin area the entire sampling procedure was repeated. The skinbiopsies were taken adjacent to each other, and the wound produced was closed by primary suture with nylon stitches in the skin.

In the surgical patients a skin-biopsy was excised after cleansing and disinfection of the skin before surgery. 


\section{Cleansing}

Cleansing consisted of a three-minute wash with cetyltrimethyl ammonium bromide (cetrimide) $0.15 \%(\mathrm{w} / \mathrm{v})$ and chlorhexidine gluconate $0.015 \%$ $(w / v)$ in aqueous solution (Savlon), followed by drying with sterile pieces of gauze.

\section{Disinfection}

Disinfection was effected by the application of $0.5 \%(\mathrm{w} / \mathrm{v})$ chlorhexidine gluconate in $62 \%(\mathrm{w} / \mathrm{v})$ ethyl alcohol (Hibitane), repeated after drying. The disinfectant was tinted with methylene blue to make it visible.

\section{Velvet Pad Procedure}

Each velvet pad was backed with aluminium foil and measured $2.0 \times 4.5 \mathrm{~cm}$. The pad was divided into two equal parts after sampling. One part was immediately placed in a tube with $4.5 \mathrm{ml}$ medium for anaerobic and aerobic culture (see Anaerobic Techniques), while the other part was transferred to a sterile $300 \mathrm{ml}$ Erlenmeyer flask containing $9 \mathrm{ml} 0.9 \%$ saline. The flask was shaken mechanically for $15 \mathrm{~min}$, the velvet pad was removed, and the suspension was centrifuged for $30 \mathrm{~min}$ at about $2000 \mathrm{~g}$. The clear supernatant was removed and the deposit streaked on blood agar plates. Samples for control of artificial contamination were included at all stages of the velvet pad rinse technique which has been outlined in detail previously (Raahave, 1975).

\section{Anaerobic Techniques}

Immediately after excision we placed the skinbiopsy in an empty sterile tube and the velvet pad in a tube with $4.5 \mathrm{ml}$ prereduced Peptone-Yeast extract basal medium (PY-medium) (Justesen et al, 1973), flushing both tubes with oxygen-free carbon dioxide. All samples were forwarded to the laboratory for anaerobic cultivation with a transport time of less than $30 \mathrm{~min}$.

The technique of anaerobic cultivation using a 'glove-box' with an oxygen-free atmosphere and prereduced anaerobically sterilized media has been described earlier (Justesen et al, 1973). Brain-heart infusion agar (Difco) supplemented by defibrinated horse blood $5 \%$, cysteine, haemin, and menadione (BAP-medium) was used as agar medium and stored for at least $24 \mathrm{~h}$ in the glove-box prior to use. Immediately on arrival at the laboratory the samples were passed through the lock into the glove-box, where the skin-biopsies were triturated in a PotterElvhjelm homogenizer in $1 \mathrm{ml} \mathrm{PY-medium} \mathrm{and}$ plated in duplicate on BAP-medium. The velvet pad samples in PY-medium were first shaken mechanically (as described) before amounts of $0.5 \mathrm{ml}$ were plated in duplicate on BAP-medium. All inoculated media were incubated for one week in $\underline{\underline{\sigma}}$ $5 \%$ carbon dioxide inside the glove-box at a temperature of $35^{\circ} \mathrm{C}$ maintained by thermostat. The samples were also cultivated aerobically on blood agar plates, incubated for $48 \mathrm{~h}$ at $35^{\circ} \mathrm{C}$.

The identification of anaerobic bacteria was $\frac{\bar{p}}{\bar{c}}$ based on methods described by Holdeman and $\stackrel{\varnothing}{\complement}$ Moore (1972). Aerobic and facultative anaerobic bacteria were grouped in Micrococcus spp, Staphy- $\overrightarrow{-}$ lococcus albus, diphtheroids, and lactobacillus? according to Gram staining, ability to grow under $\vec{\omega}$ anaerobic/aerobic conditions, and catalase pro- $\stackrel{\mathscr{S}}{\Omega}$ duction.

Neutralizing Agents of the disinfectants used in this study (Bergan and Lystad, 1972). Tests were therefore made to show 0 whether the homogenization would release the $\vec{T}$ disinfectant from the whole skin-biopsies to the $\vec{O}$ medium. One millilitre of dilutions of cultures of Staph. albus and Propionebacterium acnes, isolated from the skin and grown overnight, were homo- $\stackrel{\mathbb{Q}}{-}$ genized with cleansed and disinfected skin-biopsies $\vec{\theta}$ $\left(2 \mathrm{~cm}^{2}\right)$, and amounts of $0.5 \mathrm{ml}$ were plated $\mathrm{m}$ ㄴ duplicate on blood agar on BAP-medium. The counts before and after homogenization did nột differ significantly $(\mathrm{P}>0.05)$.

\section{Statistical Methods}

The results were obtained as viable counts and expressed as bacteria per square centimetre, on the basis of one colony equal to one bacterium with the techniquesemployed. The preinvestigative concept $\frac{7}{0}$ was that the sample distributions could not be expected to be normal, binomial or Poisson, since? bacteria are unevenly scattered on the skin. The median was therefore used to express the central tendency of the sample distributions of bacteria 0 per square centimetre, and comparisons were made by distribution-free statistical tests (Bradley, 1968). 옥

\section{Results}

As sampled by velvet pad imprints which were ? rinsed in PY-medium, the superficial flora of the $N$ skin consisted of anaerobic (P. acnes) and aerobic $N_{\omega}$ bacteria (Staph. albus and diphtheroids) (table I). There was no statistically significant difference between the two groups (Wilcoxon's test: $P>0.05$ ). Micrococcus spp. together with Staph. albus and $\stackrel{+}{+}$ diphtheroids were found in addition from velvet $\underline{T}$ pads transferred to and rinsed in ordinary saline $\stackrel{\vec{P}}{\vec{P}}$ instead of the PY-medium, yielding from $0 \cdot 1$ to $0.3 \stackrel{\triangle}{\overparen{D}}$ bacteria per $\mathrm{cm}^{2}$. 


\begin{tabular}{|c|c|c|c|c|c|}
\hline & \multirow[t]{2}{*}{ Sex } & \multirow[t]{2}{*}{ Age } & $\begin{array}{l}\text { Anaerobic } \\
\text { Bacteria } \\
\text { per } \mathrm{cm}^{2}\end{array}$ & \multicolumn{2}{|c|}{$\begin{array}{l}\text { Aerobic Bacteria } \\
\text { per } \mathrm{cm}^{2}\end{array}$} \\
\hline & & & $\begin{array}{l}\text { Proprione- } \\
\text { bacterium } \\
\text { acnes }\end{array}$ & Staph. albus & Diphtheroids \\
\hline Range & $\begin{array}{l}\mathbf{M} \\
\mathbf{F}\end{array}$ & $\begin{array}{l}21-34 \\
21-34\end{array}$ & $0-9$ & $0-16$ & $0-14$ \\
\hline
\end{tabular}

Table I Superficial bacterial flora of the skin sampled by velvet pad imprints from the thigh in 14 volunteers without disease of the skin

The deep flora, determined from the whole skinbiopsies, was dominated by a heavy occurrence of $P$. acnes and Staph. albus, while diphtheroids, Micrococcus spp., and lactobacilli were present only sporadically (table II). Although the occurrence of both anaerobic and aerobic species differed from one volunteer to another, the aerobic bacteria were present in greater numbers than the anaerobic, with median values of 60 and 36 bacteria per $\mathrm{cm}^{2}$, respectively (table III), the difference being significant at $\mathbf{P}<0.01$ (Wilcoxon's test). Volunteers 3, 6 , and 14 yielded no anaerobic bacteria on either superficial or deep sampling of the skin, but all volunteers except No. 1 showed Staph. albus also in deep samples.

No superficial sample showed bacterial growth after the cleansing/disinfection procedure, while on deep sampling by skin-biopsy, all but one sample showed absence of bacterial growth (table IV). Thus, aqueous cetrimide/chlorhexidine followed by chlorhexidine in alcohol offered a significant reduction in both the superficial and deep anaerobic and aerobic skin flora (Fisher's exact method:

\begin{tabular}{lcccc}
\hline $\begin{array}{l}\text { Volunteer } \\
\text { No. }\end{array}$ & \multicolumn{2}{l}{ No. of Bacteria per $\mathrm{cm}^{2}$} & $\begin{array}{l}\text { Anaerobic } \\
\text { Bacteria (\%) }\end{array}$ \\
\cline { 2 - 4 } & $\begin{array}{l}\text { Anaerobic } \\
\text { Bacteria }\end{array}$ & $\begin{array}{c}\text { Aerobic } \\
\text { Bacteria }\end{array}$ & Total & \\
\hline 1 & 210 & 300 & 510 & 41 \\
2 & 101 & 305 & 406 & 25 \\
3 & 0 & 58 & 58 & 0 \\
4 & 75 & 68 & 143 & 52 \\
5 & 50 & 45 & 95 & 53 \\
6 & 0 & 1143 & 1143 & 0 \\
7 & 99 & 116 & 215 & 46 \\
8 & 4 & 11 & 15 & 27 \\
9 & 1 & 10 & 11 & 9 \\
10 & 57 & 61 & 118 & 48 \\
11 & 7 & 81 & 88 & 8 \\
12 & 29 & 49 & 78 & 37 \\
13 & 43 & 28 & 71 & 61 \\
14 & 0 & 22 & 22 & 0 \\
Median & 36 & 60 & 93 & 32 \\
\hline
\end{tabular}

Table III Quantitative relationships between anaerobic and aerobic bacterial flora in whole skin-biopsies from the thigh in 14 volunteers

$P<0.001$ ). Fourteen abdominal skin-biopsies excised after antisepsis of the operation site and before visceral surgery were all without aerobic or anaerobic bacterial growth.

\section{Discussion}

ANAEROBIC AND AEROBIC SKIN BACTERIA

Anaerobic culture showed the presence of $P$. acnes or no anaerobic bacteria, which is in agreement with the work by Evans et al (1950), Marples (1969), Selwyn and Ellis (1972), and Sommerville and Noble (1973). The number of aerobic species was also remarkably small, dominated by Staph. albus.

The anaerobic skin bacteria have been reported greatly to outnumber the aerobic organisms (Evans

\begin{tabular}{|c|c|c|c|c|c|}
\hline \multirow[t]{2}{*}{ Volunteer No. } & \multirow{2}{*}{$\begin{array}{l}\text { Anaerobic Bacteria } \\
\text { per } \mathrm{cm}^{2}\end{array}$} & \multicolumn{4}{|c|}{ Aerobic Bacteria per $\mathrm{cm}^{2}$} \\
\hline & & Staph. albus & Micrococcus spp. & Diphtheroids & Lactobacilli \\
\hline 1 & 210 & 0 & 59 & 145 & 96 \\
\hline 2 & 101 & 76 & $\mathbf{0}$ & 229 & 0 \\
\hline 3 & 0 & 58 & 0 & 0 & 0 \\
\hline 4 & 75 & 25 & 0 & 43 & 0 \\
\hline 5 & 50 & 36 & 0 & 9 & 0 \\
\hline 6 & 0 & 1143 & 0 & 0 & 0 \\
\hline 7 & 99 & 22 & 90 & 4 & 0 \\
\hline 8 & 4 & 5 & 0 & 6 & 0 \\
\hline 9 & 1 & 6 & 4 & o & 0 \\
\hline 10 & 57 & 55 & 6 & 0 & 0 \\
\hline 11 & 7 & 59 & 17 & 5 & o \\
\hline 12 & 29 & 14 & 1 & 34 & 0 \\
\hline 13 & 43 & 5 & 13 & 10 & 0 \\
\hline 14 & 0 & 22 & 0 & 0 & $\mathbf{0}$ \\
\hline Median & 36 & 24 & 1 & 8 & 0 \\
\hline
\end{tabular}

Table II Deep bacterial flora in whole skin biopsies from the thigh in 14 volunteers 


\begin{tabular}{|c|c|c|c|c|c|}
\hline \multirow[t]{3}{*}{ Skin Flora } & \multirow[t]{3}{*}{ Bacteria per $\mathrm{cm}^{2}$} & \multicolumn{4}{|c|}{ No. of Volunteers } \\
\hline & & \multicolumn{2}{|c|}{ No Disinfection } & \multicolumn{2}{|c|}{ Disinfection } \\
\hline & & Anaerobic & Aerobic & Anaerobic & Aerobic \\
\hline Superficial & $\begin{array}{r}0 \\
>0\end{array}$ & $\begin{array}{l}5 \\
9\end{array}$ & $\begin{array}{l}6 \\
8\end{array}$ & $\begin{array}{r}14 \\
0\end{array}$ & $\begin{array}{r}14 \\
0\end{array}$ \\
\hline Deep & $\begin{array}{r}0 \\
>0\end{array}$ & $\begin{array}{r}3 \\
11\end{array}$ & $\begin{array}{r}0 \\
14\end{array}$ & $\begin{array}{r}14 \\
0\end{array}$ & $\begin{array}{r}13 \\
1\end{array}$ \\
\hline
\end{tabular}

Table IV Superficial and deep bacterial skin flora before and after cleansing/disinfection of a thigh area in 14 volunteers

et al, 1950; Sommerville and Noble, 1973), but we found that aerobic microorganisms predominated, which is in agreement with a few recent reports (Marples, 1969; Selwyn and Ellis, 1972). The figures for the superficial and deep occurrence of anaerobic bacteria are smaller, but not directly comparable to the quantitative findings of others, because of the differences in the sampling techniques employed. $P$. acnes is rather insensitive to oxygen and can be grown by conventional anaerobic cultivation (ie, without the use of a prereduced medium) or without special methods for transportation. Thus, other and more strictly anaerobic bacteria could be grown by the technique for transportation and cultivation employed here, but nevertheless $P$.acnes was the only species found.

As far as we are aware, the present study is the only one which attempts to deal with the superficial and the deep skin flora. But a quantitative comparison between the superficial and deep occurrence of anaerobic and aerobic bacteria was not directly possible, because of the use of velvet pads for superficial sampling and skin-biopsy for deep sampling. Our investigations demonstrated in addition that bacteria could be released from the velvet pads in PY-medium, yielding higher counts than velvet pads rinsed in saline. Less viable or damaged bacteria would probably survive better in the nutrient PY-medium than in ordinary saline, and the detergent effect of the PY-medium may have released the bacteria from the velvet pad to a higher degree.

Marples (1969) has stressed that no area of the skin can be taken as representative of the whole surface. This means that great differences will always exist between different people and between different areas of skin on the same person (Noble, 1969; Shaw et al, 1970; Holt, 1971). The skin site in itself, chosen here for cosmetic reasons in the volunteers, may be responsible for the results obtained, the extremities yielding rather low bacterial counts compared to the axilla or the forehead (Reibel et al, 1967; Noble, 1969; Holt, 1971; Selwyn and Ellis, 1972; Sommerville and Noble, 1973).
SKIN DISINFECTION AND WOUND INFECTION Chlorhexidine (Davies et al, 1954) has an antimicrobial activity against a wide range of Gram-positive? and Gram-negative bacteria, including anaerobes,,$\infty$ and in alcoholic solution is as effective as povidoneiodine (Lawrence, 1960; Lowbury et al, 1960, 1963, 궁 1964a, 1964b; Lilly and Lowbury, 1971; Selwyn@ and Ellis, 1972; Lowbury and Lilly, 1973). Manyo investigators have reported the effect of chlorhexidineon the skin when this has been artificially con-O taminated with bacteria, but there are only a few? in vivo investigations on its effect on the normalo flora of the skin, save in regard to cleansing of the hands (Myers et al, 1956; Selwyn and Ellis, 1972;0 Byatt and Henderson, 1973). The present dagav showed an almost total eradication of anaerobico and aerobic bacteria after the antiseptic proced both superficial and deep in the skin. The error dưe to transference of antiseptics must be said to be⿳亠े small, since there was no further effect during ${ }_{\mathcal{O}}^{\Phi}$ homogenization of the cleansed and disinfected $\rightarrow$ skin-biopsies, and velvet pad sampling carries over 3 only a little more than the drug amount adhering to the individual organisms (Elek and Hilson, 1954). The programme employed here, however, includes. a first step of cleansing. We believe this is essentiat? because of the detergent action exerted in the openings of hair follicles and sebaceous glands facilitating the penetration of the disinfectants too the deeply placed skin bacteria. The two-step procedure thus seems very important, converting inaccessible bacteria to accessible (Selwyn and Ellis, 1972; Lowbury and Lilly, 1973; Raahave? 1973).

The rôle of anaerobic and aerobic skin bacterio in postoperative wound infection has been studied only to a limited degree. P. acnes and Staph. albusw frequently contaminate operation wounds during surgery (Wysocki and Pech, 1968; Fitzgerald et alo 1973; Raahave, 1974), and have been involved in wound infections and septicaemia, often in con? nection with surgical implants (Wilson and Stuart, 1965; Hoffmann and Gierhake, 1969; Kamme et al 1974).

The cleansing/disinfection procedure as tested 
here must be said to eliminate to a high degree the patient's skin as a source of anaerobic and aerobic operation wound bacteria.

The investigation was supported by a research grant from the National Council for Medical Sciences.

\section{References}

Bergan, T. and Lystad, A. (1972) Evaluation of disinfectant inactivators. Acta path. microbiol. scand., Sect. B, 80, 507-510.

Bradley, J. V. (1968). Distribution-free Statistical Tests. Prentice-Hall, New Jersey.

Byatt, M. E. and Henderson, A. (1973). Preoperative sterilization of the perineum: A comparison of six antiseptics. J. clin. Path., 26, 921-924.

Davies, G. E., Francis, J., Martin, A. R., Rose, F. L., and Swain, G. (1954). 1:6-di-4'-Chlorphenyldiguanidohexane ('Hibitane)'. Laboratory investigation of a new antibacterial agent of high potency. Brit. J. Pharmacol., and Chemotherapy, 9, 192-196.

Elek, S. D. and Hilson, G. R. F. (1954). Combined agar diffusion and replica plating techniques in the study of antibacterial substances. J. clin, Path., 7, 37-44.

Evans, C. A., Smith, W. M., Johnson, E. A., and Giblett, E. R. (1950). Bacterial flora of the normal human skin. J. invest. Derm., 15, 305-324.

Fitzgerald, R. H., Peterson, L. F. A., Washington II, J. A., Van Scoy, R. E., and Coventry, M. B. (1973). Bacterial colonization of wounds and sepsis in total hip arthroplasty. J. Bone Jt Surg., 55-A, 1242-1250.

Hoffmann, K. and Gierhake, F. W. (1969). Postoperative infection of wounds by anaerobes. Germ. med. Mth., 14, 31-33.

Holdeman, L. V. and Moore, W. E. C. (Eds) (1972). The Anaerobe Laboratory Manual. Blacksburg, Virginia.

Holt, R. J. (1971). Aerobic bacterial counts on human skin after bathing. $J$. med. Microbiol., 4, 319-327.

Justesen, T., Lykkegaard Nielsen, M., and Hattel, T. (1973). Anaerobic infections in chronic prostatitis and chronic urethritis. Med. Microbiol. Immunol., 158, 237-248.

Kamme, C., Lidgren, L., Lindberg, L., and Mårdh, P.-A. (1974). Anaerobic bacteria in late infections after total hip arthroplasty. Scand. J. infect. Dis., 6, 161-165.

Lawrence, C. A. (1960). Antimicrobial activity, in vitro, of chlorhexidine. J. Amer. pharm. Ass. (Sci. Ed.), 49, 731-734.

Lilly, H. A. and Lowbury, E. J. L. (1971). Disinfection of the skin: An assessment of some new preparations. Brit. med.J., 3, 674-676.

Lowbury, E. J. L. and Lilly, H. A. (1973). Use of $4 \%$ chlorhexidine detergent solution (Hibiscrub) and other methods of skin disinfection. Brit. med. J., 1, 510-515.

Lowbury, E. J. L., Lilly, H. A., and Bull, J. P. (1960). Disinfection of the skin of operation sites. Brit. J. med., 2, 1039-1044.

Lowbury, E. J. L., Lilly, H. A., and Bull, J. P. (1963). Disinfection of hands: Removal of resident bacteria. Brit. med.J., 1, 1251-1256.

Lowbury, E. J. L., Lilly, H. A., and Bull, J. P. (1964a). Disinfection of hands: Removal of transient organisms. Brit. med. J., 2, 230-233.

Lowbury, E. J. L., Lilly, H. A., and Bull, J. P. (1964b). Methods of disinfection of hands and operation sites. Brit. med.J., 2, 531-536.

Marples, M. J. (1969). The normal flora of the human skin. Brit.J. Derm., 81, Suppl. 1, 2-13.

Montes, L. F. and Wilborn, W. H. (1970). Anatomical location of normal skin flora. Arch. Derm., 101, 145-159.

Myers, G. E., MacKenzie, W. C., and Ward, K. A. (1956). The effect of a new antiseptic (1,6-di-4'chlorophenyldiguanidohexane) on skin flora. Canad. J. Microbiol., 2, 87-93.

Nielsen, M. L., Justesen, T., and Asnaes, S. (1974). Anaerobic bacteriological study of the human liver. With a critical review of the literature. Scand. J. Gastroent., 9, 671-677.

Noble, W. C. (1969). Distribution of the micrococcaceae. Brit. J. Derm., 81, Suppl. 1, 27-32.

Raahave, D. (1973). Agar contact plates in evaluation of skin-disinfection. Dan. med. Bull., 20, 204-208.

Raahave, D. (1974). Bacterial density in operation wounds. Acta chir. scand., 140, 585-593.

Raahave, D. (1975). Experimental evaluation of the velvet pad rinse technique as a microbiological sampling method. Acta path. microbiol. scand. Sect. B., 83 (In press).

Reibel, C., Grosshans, E., Minck, R., and Bassett, A. (1967). Bactériologie de la peau saine. Bull. Soc. franc. Derm. Syph., 74, 308-311.

Selwyn, S. and Ellis, H. (1972). Skin bacteria and skin disinfection reconsidered. Brit. med. J., 1, 136-140.

Shaw, C. M., Smith, J. A., McBride, M. E., and Christopher, W. C. (1970). An evaluation of techniques for sampling skin flora. J. invest. Derm., 54, 160-163.

Sommerville, D. A. and Noble, W. C. (1973). Microcolony size of microbes on human skin. J. med. Microbiol., 6, 323-328.

Wilson, T. S. and Stuart, R. D. (1965). Staphylococcus albus in wound infections and in septicaemia. Canad. med. Ass. J., 93, 8-16.

Wysocki, S. and Pech, H. (1968). Intraoperative bakteriologische Untersuchungen bei aseptischen und bedingt aseptischen Operationen. Chirurg., 39, 39-42. 